\title{
Characterization of Casein Fractions - Comparison of Commercial Casein and Casein Extracted from Cow's Milk
}

\author{
A. Ptiček Siročić, ${ }^{\mathrm{a}, *}$ Lj. Kratofil Krehula, ${ }^{\mathrm{b}}$ \\ Z. Katančić, ${ }^{b}$ and Z. Hrnjak-Murgić ${ }^{b}$ \\ aUniversity of Zagreb, Faculty of Geotechnical Engineering, \\ Hallerova aleja 7, 42000 Varaždin, Croatia \\ ${ }^{b}$ University of Zagreb, Faculty of Chemical Engineering \\ and Technology, Marulićev trg 19, 10000 Zagreb, Croatia
}

doi: 10.15255/CABEQ.2015.2311

Original scientific paper

Received: October 2, 2015

Accepted: December 12, 2016

\begin{abstract}
Biopolymer casein was isolated from cow's milk by acid coagulation, which was initiated by acetic acid and sodium acetate in the first, and hydrochloric acid in the second process. The casein isolated by acid coagulation, i.e. by first process, and commercial casein were separated on $\alpha-, \beta-,(\alpha+\kappa)$ - and $\kappa$ casein by urea fractionation. The aim of this study was to compare various properties of commercial casein fractions with casein fractions isolated from cow's milk. The structure of casein and casein fraction samples were monitored by Fourier transform infrared spectroscopy (FTIR), and the obtained vibrational bands showed structural differences between isolated and commercial casein (presence of various amino acids), as well as their fractions. Differential scanning calorimetry (DSC) was used to determine glass transition temperature. The results showed that the glass transitions of the isolated and commercial casein were below room temperature $\left(T_{\mathrm{g}}=2-30{ }^{\circ} \mathrm{C}\right)$ due to the destruction of the samples structure that provides molecules mobility and leads to a phase transition. Thermal degradation obtained by thermogravimetric analysis (TGA) of all samples occurred in multiple steps. From the results, it is evident that 5 mass $\%$ of the each sample degraded at significantly different temperatures $\left(T_{95}\right)$, and it can be concluded that isolated casein and its fractions showed better heat stability than commercial casein and its fraction.
\end{abstract}

Key words:

acid coagulation, casein, fractions, urea fractionation, thermal properties

\section{Introduction}

Casein has been manufactured during most of the $20^{\text {th }}$ century because of the simplicity of its isolation and its usefulness in the manufacturing, pharmaceutical, cosmetic and food industries. Concurrent with its declining use in adhesives and plastics, new food applications were developed, and today, between 70 and $80 \%$ of the world's casein production is used for food ingredients ${ }^{1}$. Milk contains several protein types, among which casein accounts for about $80 \%$, and it is organized as micelles ${ }^{2,3}$ with diameter ranging from 50 to $500 \mathrm{~nm}$. It includes four protein fractions $\alpha_{1}-, \alpha_{2}-, \beta$ - and $\kappa$ casein (molar ratio $\sim 4: 1: 4: 1$, respectively) and they are different in their molecular weights ${ }^{1,4-6}$. Casein is a glycoprotein, with two cysteine forming intermolecular disulphide bridges. Unlike most proteins showing different structures of the secondary and tertiary conformations, caseins have flexible exter-

"Corresponding author: Anita Ptiček Siročić; E-mail: anitaps@gfv.hr; Tel.: +385 42 408957; Fax: +385 42313587 nal structures characterized as being random. Casein "molecules" do not form crystals, which has been taken as proof of the absence of a well-defined three-dimensional structure and of an unstable secondary structure ${ }^{1,4}$. There are several theories on the structure of the casein micelle $\mathrm{e}^{2,7-10}$ and a wide range of reviews on application of casein are available ${ }^{11-14}$. Many various amino acids form casein structure, and an FTIR investigation is a suitable technique for determining specific vibrational bands occurring due to changes in chemical composition and conformation of basic amino acids. In addition, casein fractions have a variety of properties, which, in some cases, are similar, but they are mostly different. In addition, the relative amount of each fraction differs significantly from species to species. Therefore, the aim of this study was to isolate casein from cow's milk in two different ways and compare it to commercial casein, as well as compare their fractions through the determination of thermal properties (thermogravimetric analysis and differential scanning calorimetry) and specific vibrational groups using an FTIR analysis. 


\section{Experimental}

\section{Materials}

The casein under study (99\% purity, moisture content $<13 \%$ ) was supplied by Across Organics UK and the cow's milk by Dukat d.d., Croatia (UHT sterilised milk; in $100 \mathrm{~g} / 4.6 \mathrm{~g}$ carbohydrates, $2.8 \%$ milk fat, $3.3 \mathrm{~g}$ proteins). Chemicals used for isolation and fractions separation were sodium acetate $\left(M_{\mathrm{w}}=82.03 \mathrm{~g} \mathrm{~mol}^{-1}\right.$, Merck, Germany), urea $\left(M_{\mathrm{w}}=60.06 \mathrm{~g} \mathrm{~mol}^{-1}\right.$, Sigma Chemical CO., USA), sulphuric acid $\left(M_{\mathrm{w}}=98.08 \mathrm{~g} \mathrm{~mol}^{-1}\right.$ Kemika, Croatia), ammonium sulphate $\left(M_{\mathrm{w}}=132.14 \mathrm{~g} \mathrm{~mol}^{-1}\right.$, Lach, Czech Republic).

\section{Preparation of samples}

The samples were prepared by precipitation of casein from cow's milk. The precipitation of casein coagulation was achieved by acidification in two ways ${ }^{4}$ :

a) In $100 \mathrm{~mL}$ of milk, $1 \mathrm{~mL}$ of $10 \%$ acetic acid and $1 \mathrm{~mL} 1 \mathrm{~mol} \mathrm{~L}^{-1}$ of sodium acetate were added in order to achieve $\mathrm{pH}=4.7$. The samples was then centrifuged for $10 \mathrm{~min}$ at $3000 \mathrm{rpm}$ to obtain the casein and skimmed milk. Thereupon, the casein was rinsed three times with distilled water and centrifuged at $3000 \mathrm{rpm}$ for $15 \mathrm{~min}$. The sample obtained by this procedure is called "kaz 1 ". b) The milk ( $2.8 \%$ fat) was centrifuged for 20 min at $3000 \mathrm{rpm}$. The surface layer, i.e. skimmed milk, was carefully transferred into a clean glass. The skimmed milk was acidified with a few drops of $\mathrm{HCl}$ to reduce $\mathrm{pH}$ to 4.6 (the isoelectric point of casein at which precipitation from skimmed milk starts). The sample obtained by this procedure is called "kaz 2".

After precipitation, the samples were air-dried, and then placed in an oven at a temperature of about $40{ }^{\circ} \mathrm{C}$ for 2 hours.

$$
\text { Commercial casein is called "kaz A". }
$$

\section{Separation of casein}

The method of separating casein into its fractions is based on solubility of the individual components in a urea solution. Separation of casein fractions was conducted by changing the urea concentration in acid media. The process of fractionation was carried out on samples kaz A and kaz 1, and the isolation procedure is shown in Figure 1.

\section{Characterization}

Infrared spectroscopy

The casein samples were characterized by attenuated total reflectance Fourier transform infrared spectroscopy (ATR FTIR), Spectrum One FTIR

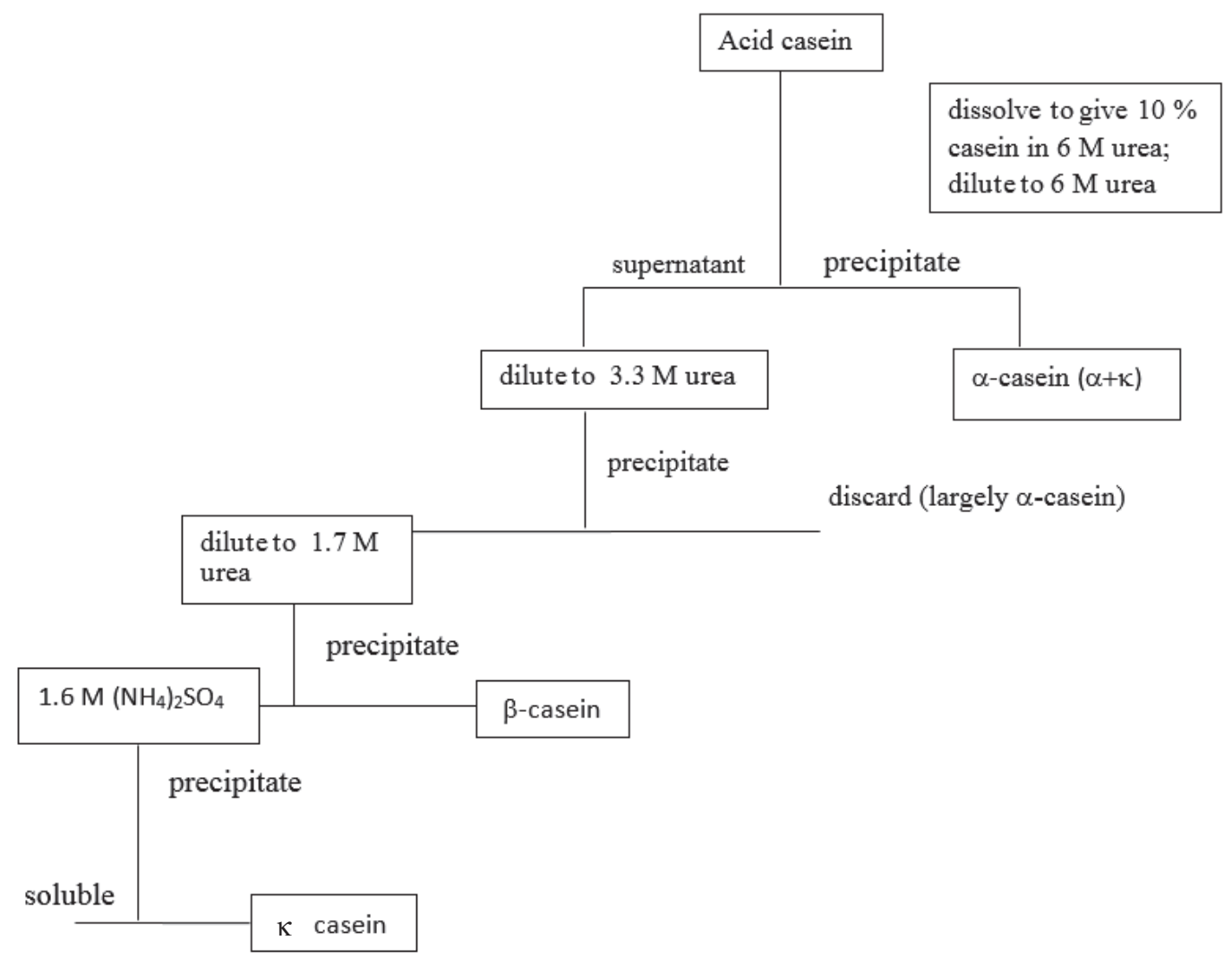

Fig. 1 - Casein fractionation ${ }^{4}$ 
spectrometer, Perkin Elmer, in the range from 4000 to $450 \mathrm{~cm}^{-1}$ with resolution of $4 \mathrm{~cm}^{-1}$.

\section{Differential scanning calorimetry}

Differential scanning calorimetry (DSC) studies were performed on Mettler Toledo DSC $823^{\mathrm{e}} \mathrm{T}$. Samples of $10 \pm 0.1 \mathrm{mg}$ were sealed in aluminium pans, heated from $0{ }^{\circ} \mathrm{C}$ to $300{ }^{\circ} \mathrm{C}$ (first heating scan), then cooled to $0^{\circ} \mathrm{C}$ (cooling scan), and finally heated from $0{ }^{\circ} \mathrm{C}$ to $300{ }^{\circ} \mathrm{C}$ (second heating scan) at the same heating/cooling rate of $10^{\circ} \mathrm{C}$. All the experiments were carried out under nitrogen atmosphere.

\section{Thermogravimetric analysis}

Thermogravimetric analysis (TGA) of the studied samples was carried out using a TA Instruments Q500 analyser (Perkin Elmer). The results were obtained for the temperature range from $25^{\circ} \mathrm{C}$ to 600 ${ }^{\circ} \mathrm{C}$ at a heating rate of $10{ }^{\circ} \mathrm{C} \mathrm{min}^{-1}$ under the flow of $\mathrm{N}_{2}$ atmosphere. Nitrogen was used as a carrier gas with a constant flow rate of $100 \mathrm{~mL}$ during the analysis. Three replicates were run for each sample, and the average value was reported. Uncertainty of initial mass loss and maximum loss rate temperatures was less than $1.3^{\circ} \mathrm{C}$, while char residue uncertainty was 1.5 mass $\%(2 \sigma)$.

\section{Scanning electron microscopy}

Scanning electron microscopy (SEM) was utilized to examine the morphology of the studied samples using Tescan Vega $5136 \mathrm{MM}$ at $20 \mathrm{kV}$ with BSE Detector. The samples were gold sputtered for examining.

\section{Results and discussion}

\section{FTIR analysis}

Figure 2 shows the FTIR spectrum of the commercial casein (kaz A) and the samples obtained by two various procedures ( $\mathrm{kaz} 1, \mathrm{kaz} 2$ ). Casein is composed of 21 various amino acids (Table 1), and it behaves differently from other proteins; it is highly flexible and does not form a crystalline structure, and its conformation resembles a denatured globular protein. In addition, casein creates clusters through aggregation of amino acids, which results in formation of hydrophilic and hydrophobic domains. Casein is characterized by vibrational bands at 2920 and 2850 $\mathrm{cm}^{-1}$ of $\mathrm{CH}_{2}$ groups, i.e. symmetric and asymmetric stretching bonds. Those vibrations indicate the presence of amino acids with a higher concentration of $\mathrm{CH}_{2}$ groups, such as lysine, which contains six carbon atoms in the side chains as well as arginine that contains three $\mathrm{CH}_{2}$ groups in the line. Strong vibrational bands at $1742 \mathrm{~cm}^{-1}$ indicate the presence of carbonyl groups $(\mathrm{C}=\mathrm{O})$. Usually, bands of the carbonyl groups occur in the range of $1725-1750 \mathrm{~cm}^{-1}$, but in our sample, these bands were shifted to higher value, which indicates the interactions in its surroundings, i.e. the presence of strong hydrogen bonds. Furthermore, a vibration peak of carbonyl groups can be seen in the interval between 1300 and $1000 \mathrm{~cm}^{-1}$ as well as at 1652 and $1585 \mathrm{~cm}^{-1}$ the area of amide stretching (NHCO). The vibrational bands at $718 \mathrm{~cm}^{-1}$ can be seen on the spectrum, which shows the vibration of $\mathrm{CH}_{2}$ bond and their presence in the $\left(-\mathrm{CH}_{2}\right)_{\mathrm{n}}$ groups.

When we compare the samples of commercial casein (kaz A) and kaz 2 to sample kaz 1, the appearance of vibrational band of carboxyl $(\mathrm{COOH})$ groups at $3280 \mathrm{~cm}^{-1}$ is evident. The lack of washing casein sample after its precipitation from the whole milk in an acidic medium could explain the occurrence of these bands. On the other hand, the presence of the $\mathrm{COOH}$ groups in commercial casein could be attributed to stabilization of the sample in order to prevent its deterioration and prolong durability.

Furthermore, FTIR spectra of samples kaz A and kaz 2 show differences in the intensity of individual vibrational bands, which can be explained by the variety in the structural units of proteins, i.e. in certain types of amino acids that are constituent parts of protein casein ${ }^{15}$. As it is known from the literature $^{16-19}$, casein shows a high degree of heterogeneity, meaning that it consists of several proteins that vary considerably in composition and functions.

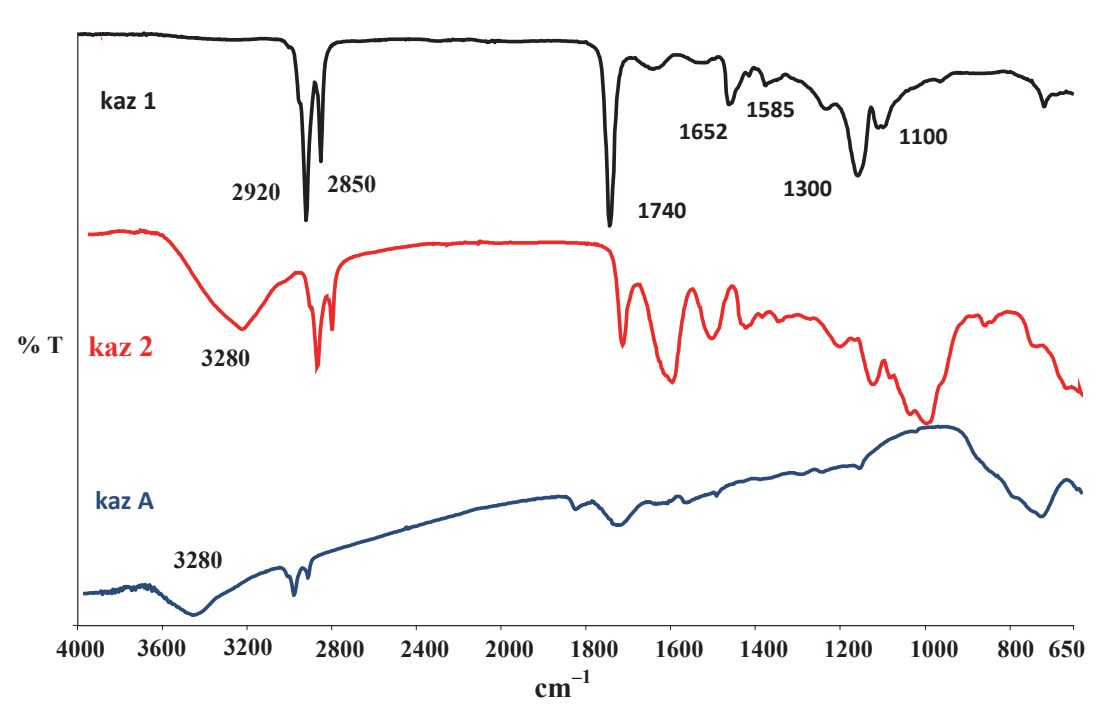

Fig. 2 - FTIR spectra of samples kaz 1, kaz 2, and kaz A 
Table 1 -Amino acids and their structural formulas

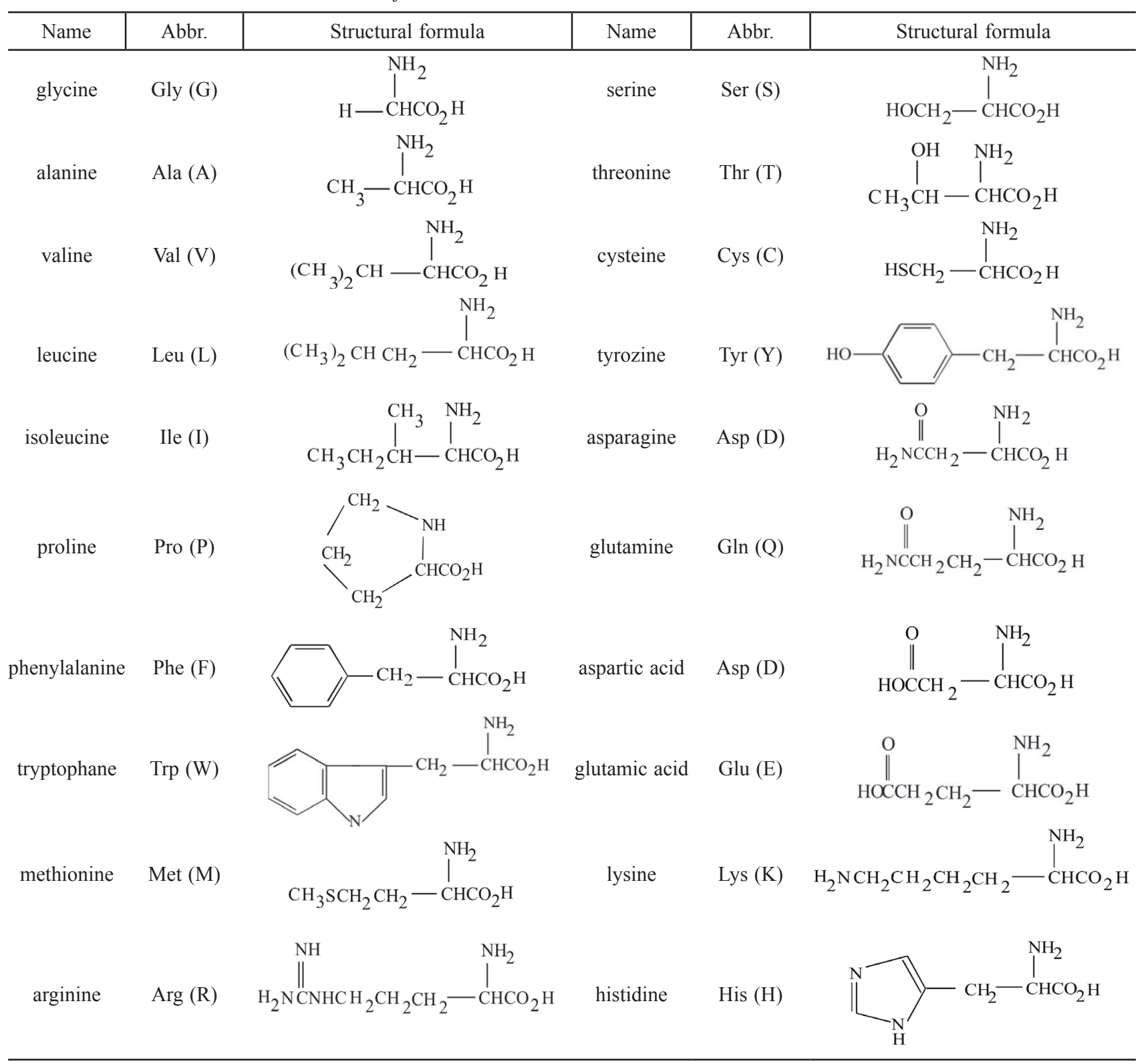

As mentioned previously, the structures of commercial and precipitated casein are different as are the structures of similar fractions. Fractions obtained from commercial casein do not contain a vibrational band of the carbonyl group at $1740 \mathrm{~cm}^{-1}$, but show very weak vibrations of $\mathrm{CH}$ groups at 2920 and $2850 \mathrm{~cm}^{-1}$ (Figure 3), while all fractions of precipitated casein contain stronger vibrations of mentioned groups, Figure 4. The peak at $1461 \mathrm{~cm}^{-1}$ indicates the vibration of $\mathrm{C}-\mathrm{H}$ bond from $\mathrm{CH}_{2}$ groups, while the weak vibration at $1375 \mathrm{~cm}^{-1}$ (fraction $\beta$ kaz A) relates to the presence of a methylene group and a tertiary carbon atom $\left(-\mathrm{CH}\left(\mathrm{CH}_{3}\right)-\right)$, Scheme 1. A methylene group is located in a few amino acids (alanine, valine, leucine, isoleucine, and methionine), proving that their presence in the casein fractions has a low concentration.

If we compare the obtained fractions $(\alpha, \beta, \kappa$ and $\alpha+\kappa)$ of commercial and precipitated casein, it is evident that $\beta$ and $\kappa$ casein have a very similar<smiles>[R]C(NC(=O)C(N)CCCNC(=N)N)C(=O)NC(C)C(=O)O</smiles> 


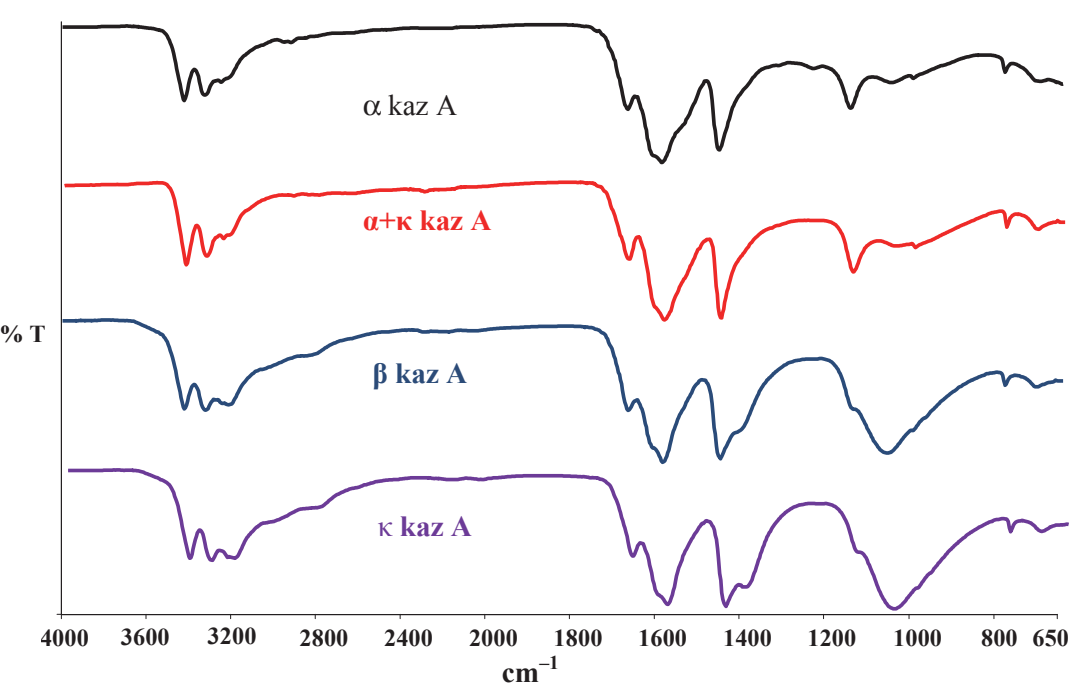

Fig. 3 - FTIR spectra of commercial casein fractions

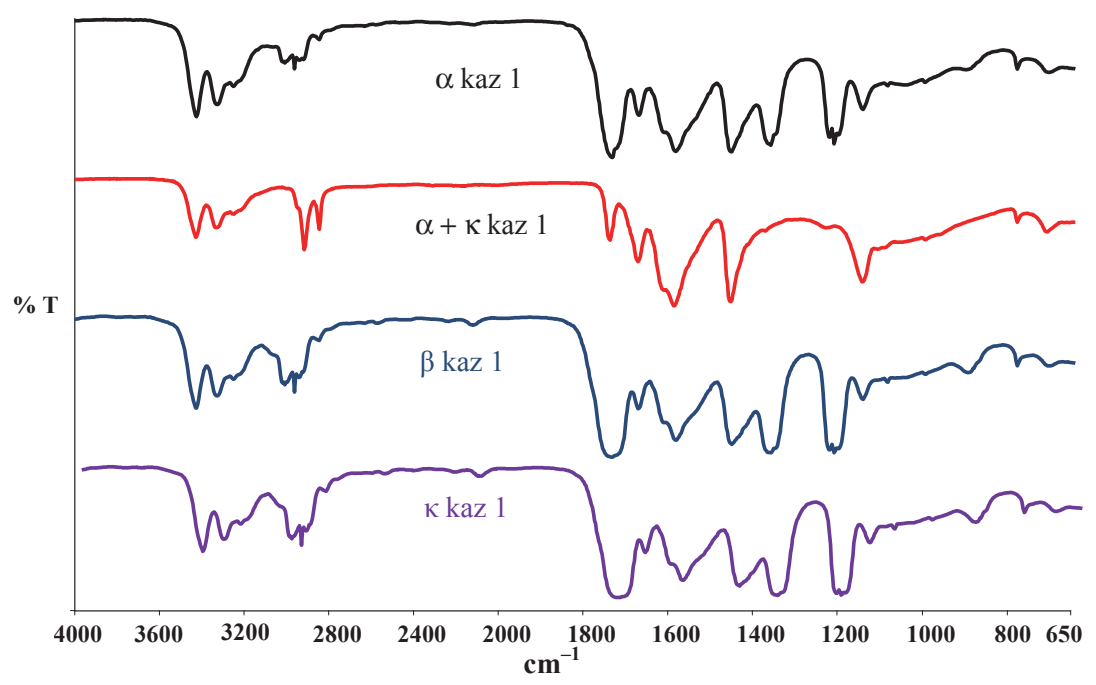

Fig. 4 - FTIR spectra of precipitated casein fractions

spectrum with a single, extremely wide, vibrating ribbon in the field of $1200-1000 \mathrm{~cm}^{-1}$. Such behaviour can be explained by the almost similar structure of these fractions in the observed vibrational bands area, Scheme 2 .

On the other hand, $\alpha$ and $\alpha+\kappa$ fractions show the weak multiple bands in the area from 1200 to $1000 \mathrm{~cm}^{-1}$. If we compare $\beta$ and $\kappa$ fractions with $\alpha$ fraction (Figure 4), it is evident that $\alpha$ fraction shows a weaker vibration of $\mathrm{CH}$ groups at 2920 and
$2850 \mathrm{~cm}^{-1}$. Furthermore, $\alpha+\kappa$ fraction indicates a weaker vibration of the carbonyl group in comparison to $\alpha$ fraction.

This behaviour can be explained by the fact that $\mathrm{k}$ fraction has a different structural timber ${ }^{20-23}$ in comparison to $\alpha$ casein, Scheme 3.

\section{Differential scanning calorimetry}

Differential scanning calorimetry is one of the frequent methods for determining the thermal properties of polymer materials. Generally, thermal properties as well as all other properties of polymers are a reflection of their chemical composition and structure. By monitoring changes in thermal properties, it is possible to follow the changes in polymer structure. It is important to determine the degradative changes in the milk proteins during their storage, sterilization and production of dairy products. One of the aims of this study was to determine which casein fractions were subject to modifications due to heat treatment. The DSC analysis of casein (Fig. 5) indicates an endothermic processes developing within the $2-40{ }^{\circ} \mathrm{C}$ temperature range. DSC curves show two intensive peaks at $11{ }^{\circ} \mathrm{C}$ and $30{ }^{\circ} \mathrm{C}$ for kaz 1 and kaz 2, while for the commercial sample of casein (kaz A) these peaks were not observed. Kaz A shows the response on 2 ${ }^{\circ} \mathrm{C}$, which can be defined as the glass transition temperature, $T_{\mathrm{g}}$. On the other hand, the $T_{\mathrm{g}}$ for kaz 1 and kaz 2 may be at $11{ }^{\circ} \mathrm{C}$, while the second response at approximately $30{ }^{\circ} \mathrm{C}$ could be attributed to the beginning of vaporization of water present in ca$\operatorname{sein}^{24,25}$.

Literature data indicate many different values for the glass transition temperature as well as problems in determining $T_{\mathrm{g}}$ of casein because of water evaporation, which appears as a very broad endothermic peak covering the detection area of glass transition $^{24-26}$. Furthermore, it is also known that casein shows a glass transition temperature below

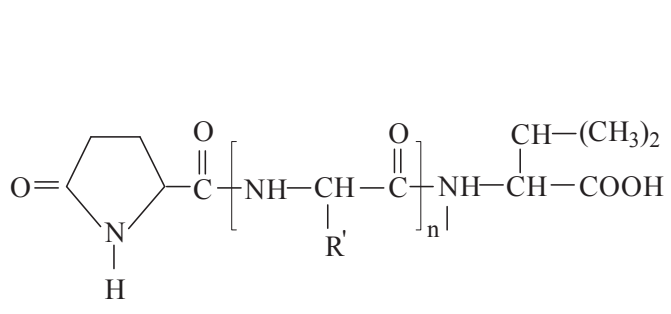

Scheme 2 - Structural formula of $\kappa$ casein<smiles></smiles>

Scheme 3 - Structural formula of $\alpha$ casein 
room temperature. The observed samples were sticky during measurement at ambient temperature, indicating the rubbery state at this temperature resulting in $T_{\mathrm{o}}$ below room temperature. Generally, the $T_{\mathrm{g}}$ of synthetic polymers as well as natural poly-

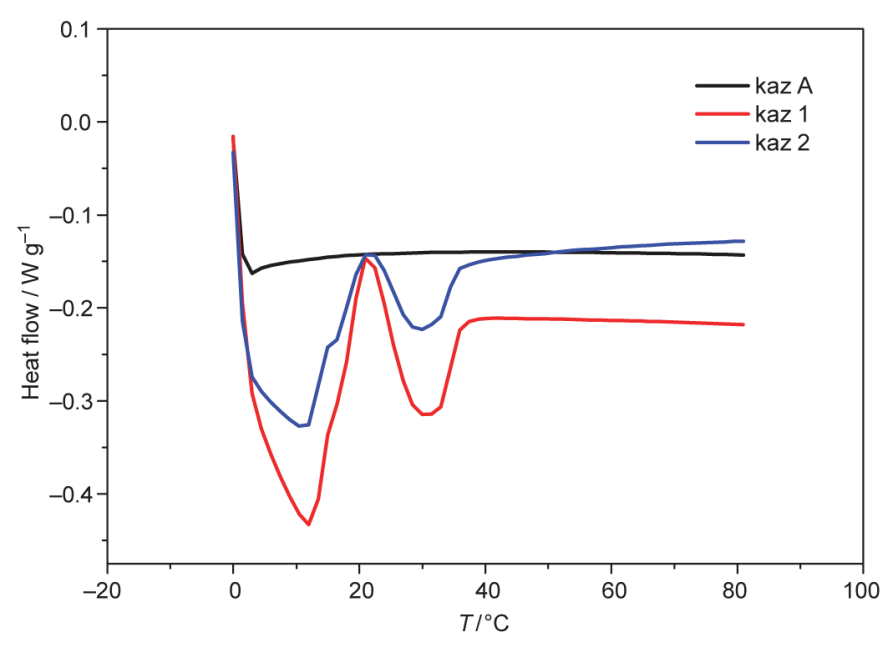

Fig. 5 - DSC curves of samples

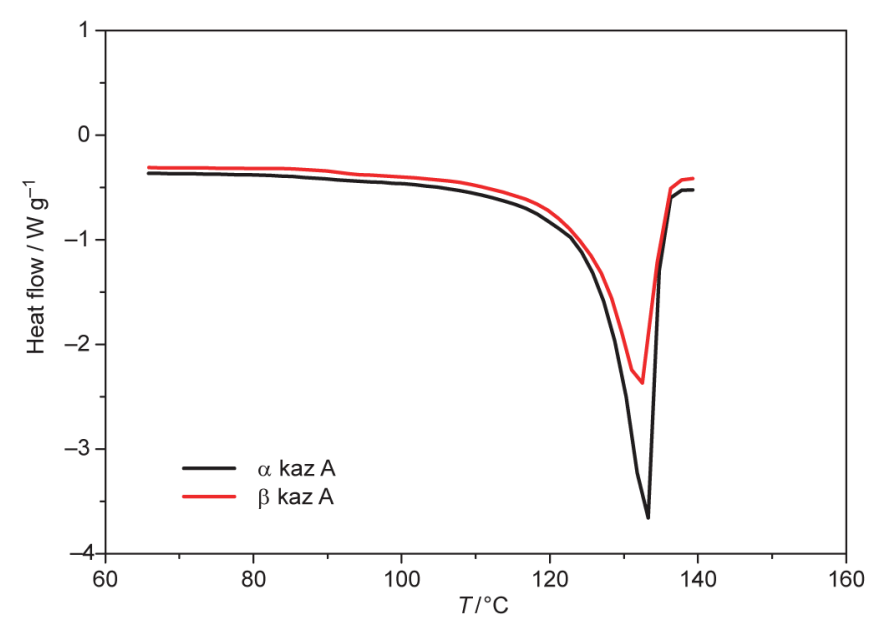

Fig. 6 - DSC curves of $\alpha \mathrm{kaz} A$ and $\beta \mathrm{kaz} A$

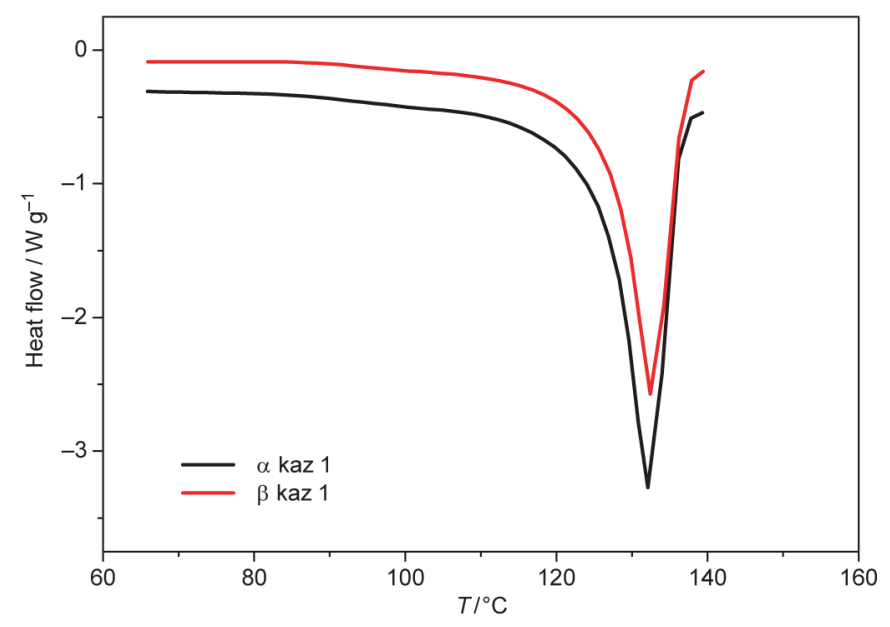

Fig. $7-$ DSC curves of $\alpha$ kaz 1 and $\beta$ kaz 1 mers depends on their molecular weight, i.e. $T_{\mathrm{g}}$ increases with molecular weight ${ }^{27}$. Therefore, ${ }^{g}$ the glass transition of polymers that have a distribution of molecular weight is considered to occur over a wide range of temperatures, and the $T_{\mathrm{g}}$ of those polymers cannot be reliably detected within the limited sensitivity of an instrument. Molecular weight of casein moves in a very wide range, i.e. from 33,600 to $375,000 \mathrm{~g} \mathrm{~mol}^{-1}{ }^{1}$. In order to precisely determine the glass transition temperature, a suitable method that could be used would be RHC DSC, i.e. rapid heat-cool scanning calorimetry ${ }^{28}$.

Figures 6 and 7 show the thermograms of $\alpha$ and $\beta$ fractions of commercial and precipitated casein, respectively. A very intensive peak at approximately $130{ }^{\circ} \mathrm{C}$ is observed and it is assumed that it represents the glass transition of casein, but may also indicate the temperature of water evaporation. In this case, it could be a glass transition temperature because $\alpha$ and $\beta$ fractions do not have a wide interval of molecular weight distribution, i.e. values of molecular masses are very close to each other $\left(M_{\mathrm{m}} \alpha\right.$ casein $=22068$ to $22723 \mathrm{~g} \mathrm{~mol}^{-1} ; M_{\mathrm{m}} \beta$ casein $=23939$ to $\left.24089 \mathrm{~g} \mathrm{~mol}^{-1}\right)$, and the $T_{\mathrm{g}}$ can be precisely determined ${ }^{1}$. Generally, close values of molecular masses cause much difficulty during the separation into individual casein fractions based on differences in solubility. A narrower endothermic peak indicates a homogeneous structure of a casein and low concentration of orthophosphate, as well as less water content.

\section{Thermogravimetric analysis}

The thermal stability of material reflects its chemical composition and structure, and it is defined as the ability of a material to keep its basic physical properties that are required for a particular purpose during a certain time and at a certain temperature. Thermogravimetric analysis (TGA) is the most commonly used method to evaluate thermal stability and mechanism of material degradation. The results of TG analysis of the studied samples are shown in Table 2, measured in temperatures ranging from $25^{\circ} \mathrm{C}$ to $600{ }^{\circ} \mathrm{C}$ at a heating rate of 10 ${ }^{\circ} \mathrm{C} \mathrm{min}^{-1}$. As it can be seen from the Table 2, multistage decomposition is present except for sample kaz 1, and that can be explained by the presence of various ranges of molecular weight which decompose in a certain temperature range.

Since the degradation proceeds at low temperatures for all samples (where the chemical bonds cannot be broken), it could be attributed to the elimination of the water physically retained by ca$\operatorname{sein}^{26,28}$. The results show that the first stage of casein degradation develops in the temperature range from approximately $40-150{ }^{\circ} \mathrm{C}$ for all samples, while the second stage is clearly visible for kaz 2 in 
Table $2-$ TGA results of studied samples, initial degradation temperatures $\left(T_{95}\right)$, temperatures of degradation peaks maximum $\left(T_{\max }\right)$ and char residue

\begin{tabular}{l|r|r|c|c|c}
\hline \multirow{2}{*}{ Sample } & \multirow{2}{*}{$T_{95} /{ }^{\circ} \mathrm{C}$} & \multicolumn{3}{|c|}{$T_{\max } /{ }^{\circ} \mathrm{C}$} & \multirow{2}{*}{ Residue/\% } \\
\cline { 3 - 6 } & & $T_{\max 1}$ & \multicolumn{1}{c}{$T_{\max 2}$} & $T_{\max 3}$ & \\
\hline kaz A & 84.49 & 59.99 & 189.94 & 321.78 & 27.09 \\
kaz 1 & 104.03 & 49.25 & 348.23 & & 12.42 \\
kaz 2 & 92.33 & 65.06 & 202.02 & 346.03 & 17.28 \\
$\alpha$ kaz A & 146.25 & 194.55 & 238.24 & 314.07 & 6.56 \\
$\alpha$ kaz 1 & 152.40 & 194.84 & 235.71 & 318.53 & 17.62 \\
$\beta$ kaz A & 90.05 & 205.49 & 304.94 & & 9.36 \\
$\beta$ kaz 1 & 158.41 & 207.74 & 226.73 & 313.53 & 4.03 \\
\hline
\end{tabular}

the temperature range from $150-250{ }^{\circ} \mathrm{C}$ followed by the third decomposition stage. From the initial thermal degradation temperature $\left(T_{95}=85{ }^{\circ} \mathrm{C}\right)$ and the temperature at the maximum degradation rate $\left(T_{\max }=321{ }^{\circ} \mathrm{C}\right)$, it can be concluded that kaz A shows lower thermal stability than sample kaz 1 $\left(T_{95}=104^{\circ} \mathrm{C}, T_{\max }=348^{\circ} \mathrm{C}\right)$. Furthermore, visible changes are observed for the sample kaz 2 in temperature interval from $55-220{ }^{\circ} \mathrm{C}$ due to the gradual softening of casein followed by its decomposition in area from $220-450{ }^{\circ} \mathrm{C}$. Above $400{ }^{\circ} \mathrm{C}$, no significant decomposition of samples is observed, revealing the end of the thermal degradation ${ }^{29-32}$. For all studied samples, the obtained biochar (about $10-$ $20 \%$ ) is a compact solid material with highly developed porosity structure, and the investigation of its properties will be investigated in other studies.
Higher char residue may be the result of a different decomposition mechanism. It is assumed that some synergistic action was related to the formation of a protective layer during combustion on the sample surface acting as thermal insulation layer. It reduces evaporation and diffusion of fuel gases into air, and it reduces heat release rate and mass loss rate, thus improving thermal properties. If we compare the $\alpha$ and $\beta$ fractions of kaz 1 with fractions of commercial casein (kaz A), we can concluded that $\alpha$ and $\beta$ fractions of kaz 1 are more thermally stable than fractions of kaz A. For example, $\beta$ fractions of kaz A start decomposing at $90{ }^{\circ} \mathrm{C}$, while the same fraction of kaz 1 begins degradation at $158^{\circ} \mathrm{C}$.

\section{Scanning electron microscopy}

Notwithstanding their abundance and countless number of studies, still there is no unified picture of their structure and properties ${ }^{25-29}$. Figure 8 shows the micrographs of commercial casein and sample kaz 1. It can be seen that the casein micelles have a porous structure due to high water content. Generally, the micelles (usually arranged in a diameter size from 50 to $500 \mathrm{~nm}$ ) contain about $2 \mathrm{~g}$ water/g protein, and there were $10^{14}-10^{16} \mathrm{~mL}^{-1}$ milk $^{29,32}$. The protein fraction of the casein micelles, which represents $\sim 93 \%$ of its dry mass, is composed of four individual gene product components, denoted as $\alpha_{1}, \alpha_{2}, \beta-$ and $\kappa$-casein, which differ in primary structure and type, and degree of post-translational modification.

The internal structure of the casein micelles, i.e. showing how the various components are distributed within the casein micelle, was modelled ac-
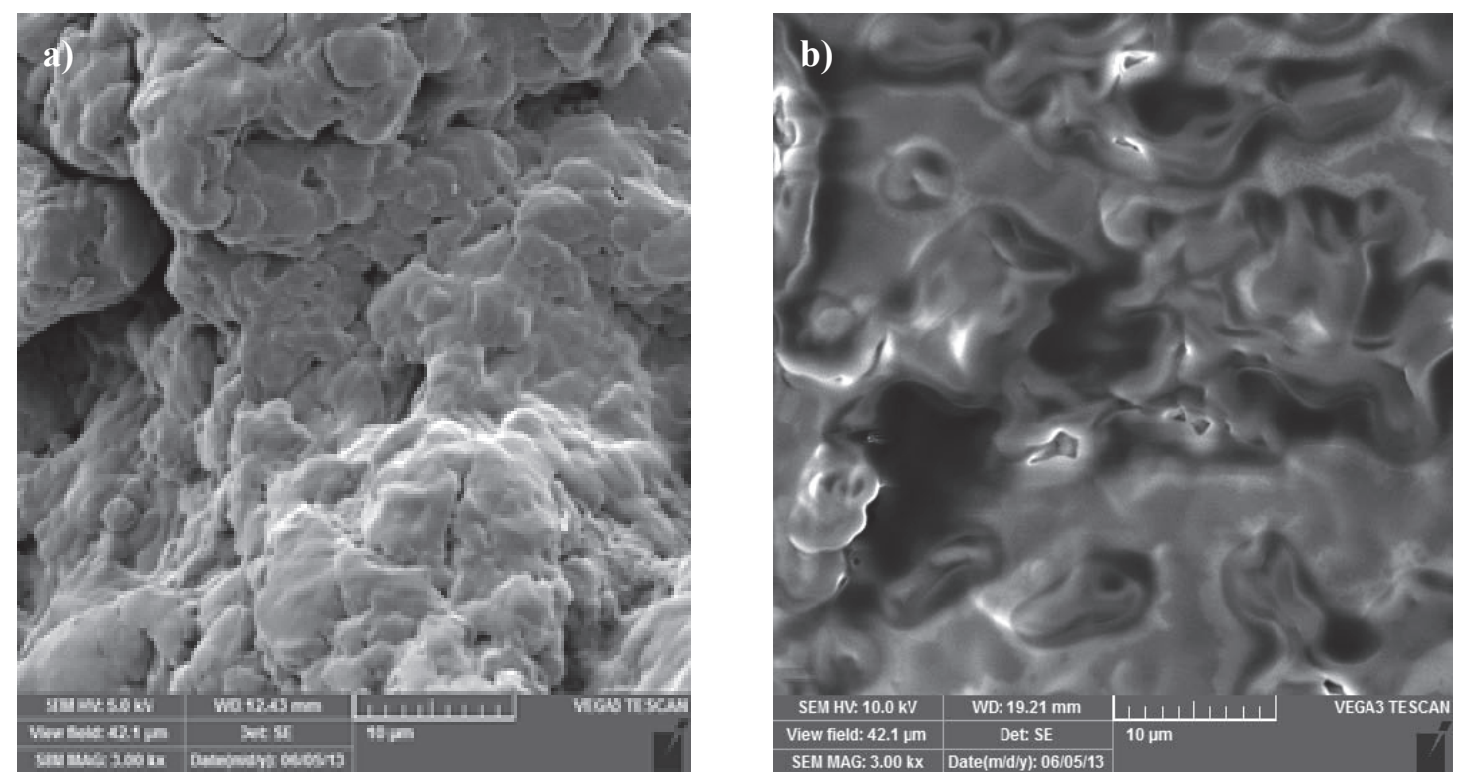

Fig. 8 - SEM micrographs of a) kaz $A$ and b) kaz 1 
cording to three different models advocated in the literature; i.e. the classical sub-micelle model, the nanocluster model, and the dual binding model ${ }^{33-35}$. Furthermore, the micelles are usually spherical in shape and their surface is rough. Such rough structure can be seen in Figure 8a, as can the clusters of micelles formed from a number of aggregated sub-micelles. Sub-micelles may be connected via a cluster of calcium phosphate, and thus, the sub-micelle aggregate and form casein micelles. As was mentioned previously, the structure of casein micelles depends on temperature changes, $\mathrm{pH}$, ionic strength between the bonds, water activity, etc., followed by the changes in particle size and content of sub-micelles in casein. However, it can be concluded that the structure of casein micelles is amorphous in the presence of micelles clusters of various size, and the porosity of the structure can be affected by the casein preparation process (also drying process) to give a casein with lower porosity. Therefore, various parameters of casein preparation have significant effect on the size of the aggregates of casein micelles and thus its stability and potential use.

\section{Conclusion}

Biopolymer casein consists of four principal proteins, which represent almost the whole casein content although its structure is very heterogeneous due to relatively small variations in one or more of the proteins. Separation of casein samples onto fractions resulted in the destruction of its structure, which was confirmed by FTIR analysis. Considering the intensity and shape of specific vibrational bands, it can be concluded that the structure of commercial casein significantly differs from the precipitated casein, as well as their fractions, i.e. various amino acids that form casein are present in each sample. The analysis of casein by thermogravimetric method under nitrogen atmosphere shows multistage decomposition and initial degradation temperature $\left(T_{95}\right)$ indicating better thermal stability of isolated casein ( $\mathrm{kaz} 1 T_{95}=104{ }^{\circ} \mathrm{C}$, $\operatorname{kaz} 2 T_{95}=92$ ${ }^{\circ} \mathrm{C}$ ) and its fractions than commercial casein (kaz A $T_{95}=84{ }^{\circ} \mathrm{C}$ ). The results of differential scanning calorimetry showed quite a low glass transition temperature of casein samples with the extended peak indicating heterogeneous structure, which was confirmed by FTIR analysis. Porous and amorphous structure of samples is obtained by scanning electron microscopy, and it can be seen that the casein micelle is roughly spherical, though it does not have a smooth surface; it consists of smaller units, called sub-micelles, which contain primarily casein and have a mixed composition; sub-micelles can aggregate until they form a micelle.

\section{Literature}

1. Schrieke, R. R., Winter, G., Casein, in Mark, H. M., Bikales, N. M., Overberger, C. G., Mendes, G. (Eds.), Encyclopaedia of Polymer Science and Engineering, Vol. 2, Wiley-Interscience Publ., New York, 1985, pp 685-691.

2. Elzoghby, A. O., Abo El-Fotoh, W. S., Elgindy N. A., Casein-based formulations as promising controlled release drug delivery systems, J. Control. Release. 153 (2011) 206. doi: https://doi.org/10.1016/j.jconrel.2011.02.010

3. Sahin, S., Selek, H., Ponchel, G., Ercan, M. T., Sargon, M., Hincal, A. A., Kas, H. S., Preparation, characterization and in vivo distribution of terbutaline sulfate loaded albumin microspheres, J. Control. Release. 82 (2002) 345. doi: https://doi.org/10.1016/S0168-3659(02)00141-4

4. Fox, $P$. F., Milk proteins: general and historical aspects, in Fox, P. F., McSweeney, P. L. H. (Eds.), Advanced Dairy Chemistry, Proteins, Parts A\&B, Vol. 1, Kluwer Academic/ Plenum Publ., New York, 2003, pp 1-48.

5. Singh, $H$., $Y e, A$., Interactions and functionality of milk proteins in food emulsions, in Thompson, A., Boland, M. J., Singh, H. (Eds.), Milk Proteins, from Expression to Food, Elsevier, 1st edn. Academic Press, Amsterdam, 2009, pp 321-345.

6. Dickinson, E., van Vliet, T., Colloidal aggregation: Mechanisms and implications, in Dickinson, E., Vliet, T. (Eds.), Food Colloids, Biopolymers and Materials, Royal Society of Chemistry, Cambridge, 2003, pp 68-83. doi: https://doi.org/10.1039/9781847550835-00068

7. de Kruif, T., Huppertz, C. G., Urban, V. S., Petukhov, A. V., Casein micelles and their internal structure, Adv. Colloid. Interfac. 171-172 (2012) 36. doi: https://doi.org/10.1016/j.cis.2012.01.002

8. Dalgleish, D. G., Structure-function relationship of caseins, in Damodaran, S., Paraf, A. (Eds.), Food Proteins and their Applications, Marcel Dekker Inc, New York, 1997, pp 199223.

9. Fox, P. F., Brodkorb, A., The casein micelle: Historical aspects, current concepts and significance, Int. Dairy. J. 18 (2008) 677. doi: https://doi.org/10.1016/j.idairyj.2008.03.002

10. Farrell, Jr. H. M., Qi, P. X., Wickham, E. D., Unruh, J. J., Secondary structural studies of bovine caseins: structure and temperature dependence of $\beta$-casein phosphopeptide (1-25) as analyzed by circular dichroism, FTIR Spectroscopy, and Analytical Ultracentrifugation, J. Protein. Chem. 21 (2002) 307.

doi: https://doi.org/10.1023/A:1019992900455

11. Dong, $Q$., Gu, L., Synthesis of AN-g-casein copolymer in concentrated aqueous solution of sodium thiocyanate and AN-g-casein fiber's structure and property, Eur. Polym. J. 38 (2002) 511. doi: https://doi.org/10.1016/S0014-3057(01)00214-2

12. Choi, J., Horne, D. S., Lucey, J. A., Determination of molecular weight of a purified fraction of colloidal calcium phosphate derived from the casein micelles of bovine milk, J. Dairy. Sci. 94 (2011) 3250. doi: https://doi.org/10.3168/jds.2010-3762

13. Liu, Y., Guo, R., pH-dependent structures and properties of casein micelles, Biophys. Chem. 136 (2008) 67. doi: https://doi.org/10.1016/j.bpc.2008.03.012

14. Dalgleish, D. G., The basis of structure in dairy-based foods: Casein micelles and their properties, in Boland, M., Golding, M., Singh, H. (Eds.), Food Structures, Diges- 
tion and Health, Academic Press, New York, 2014, pp $83-105$.

doi: https://doi.org/10.1016/B978-0-12-404610-8.00003-7

15. Horne, D. S., Casein Interaction: casting light on the Black Boxes, the structure in dairy products, Int. Dairy. J. 8 (1998) 171. doi: https://doi.org/10.1016/S0958-6946(98)00040-5

16. Ng-Kwai-Hang, K. F., Milk proteins; Heterogeneity, fractionation and isolation, in Roginski, H., Fuquay, J. W., Fox, P. F. (Eds.), Encyclopaedia of dairy sciences, Academic Press, London, 2002, pp 1881-1902. doi: https://doi.org/10.1016/B0-12-227235-8/00317-5

17. Ng-Kwai-Hang, K. F., Grosclaude, F., Genetic polymorphism of milk proteins, in Fox, P. F., McSweeney, P. L. H. (Eds.), Advanced dairy chemistry-1: proteins, Kluwer academic/Plenum Publ., New York, 2003, pp 739-816.

18. Ng-Kwai-Hang, K. F., Hayes, J. F., Moxley, J. E., Variation in milk protein concentrations associated with genetic polymorphism and environmental factors, J. Dairy Sci. 70 (1987) 563. doi: https://doi.org/10.3168/jds.S0022-0302(87)80042-5

19. Gerard Barrya, J., Donnellya, W. J., Casein compositional studies: II. The effect of secretory disturbance on casein composition in freshly drawn and aged bovine milks, J. Dairy Res. 48 (1981) 437. doi: https://doi.org/10.1017/S0022029900021919

20. Curley, D. M., Kumosinski, T. F., Unruh, J. J., Farrell, Jr $H$. M., Changes in the secondary structure of bovine casein studied by Fourier transform infrared spectroscopy: effects of calcium and temperature, J. Dairy Sci. 81 (1998) 3154. doi: https://doi.org/10.3168/jds.S0022-0302(98)75881-3

21. Cross, K. J., Huq, N. L., Stanton, D. P., Sum, M., Reynolds, $E$. $C$., NMR studies of a novel calcium, phosphate and fluoride delivery vehicle- $\alpha_{\mathrm{S} 1}$-casein (59-79) by stabilized amorphous calcium fluoride phosphate nanocomplexes, Biomaterials. 25 (2004) 5061.

22. Wahlgren, N. M., Leonil, J., Dejmek, P., Drakenberg, T. Two-dimensional NMR study of the b-casein peptide 1-25, Biochim. Biophys. Acta. 1202 (1993)121. doi: https://doi.org/10.1016/0167-4838(93)90072-Y

23. Farrell, Jr. H. M., Wickham, E. D., Unruh, J. J., Qi, P. X., Hoagland, P. D., Secondary structural studies of bovine caseins: temperature dependence of $\beta$-casein structure as analysed by circular dichroism and FTIR spectroscopy and correlation with micellization, Food. Hydrocolloid. 15 (2001) 341 . doi: https://doi.org/10.1016/S0268-005X(01)00080-7
24. Mizuno, A., Mitsuiki, M., Motoki, M., Glass transition temperature of casein as affected by transglutaminase, J. Food. Sci. 64 (1999) 796. doi: https://doi.org/10.1111/j.1365-2621.1999.tb15914.x

25. www.tainstruments.com/The glass transition of casein by rapid heat cool (RHC) DSC, TA 350 (Accessed 29 June 2014)

26. Somanathan, N., Subramanian, V., Mandal, A. B., Thermal stability of modified caseins, Thermochim. Acta 302 (1997) 47. doi: https://doi.org/10.1016/S0040-6031(97)00107-X

27. Chartoff, R. P., Thermoplastic polymers, in Turi, E.A. (Ed.), Thermal Characterization of Polymeric Materials, 2nd ed., Vol. 1, Academic Press, New York, 1997, pp 483-743.

28. Bengoechea, C., Arrachid, A., Guerrero, A., Hill, S. E., Mitchell, J. R., Relationship between the glass transition temperature and the melt flow behavior for gluten, casein and soya, J. Cereal. Sci. 45 (2007) 275 doi: https://doi.org/10.1016/j.jcs.2006.08.011

29. Walstra, P., Casein sub-micelles: do they exist?, Int. Dairy. J. 9 (1997) 189. doi: https://doi.org/10.1016/S0958-6946(99)00059-X

30. Purevsuren, B., Davaajav, Y., Thermal analysis of casein, J. Therm. Anal. Calorim. 65 (2001) 147. doi: https://doi.org/10.1023/A:1011532819792

31. Alongi, J., Carletto, R. A., Bosco, F., Carosio, F., Di Blasio, A., Cuttica, F., Antonucci, V., Giordano, M., Malucelli, G., Caseins and hydrophobins as novel green flame-retardants for cotton fabrics, Polym. Degrad. Stabil. 99 (2014) 111. doi: https://doi.org/10.1016/j.polymdegradstab.2013.11.016

32. Walstra, P., On the stability of casein micelles, J. Dairy Sci 73 (1990) 1965. doi: https://doi.org/10.3168/jds.S0022-0302(90)78875-3

33. Swaisgood, H. E., Chemistry of the caseins, in Fox, P. F., Sweeney, P. L. H. (Eds.), Advanced Dairy Chemistry-1. Proteins, 3rd edn, Kluwer Academic/Plenum, New York, 2003, pp 139-201. doi: https://doi.org/10.1007/978-1-4419-8602-3_3

34. Schmidt, D. G., Association of casein and casein micelle structure, in Fox, P. F. (Ed.), Developments in Dairy Chemistry-1. Proteins, Applied Science Publ., London, 1982, pp 61-86.

35. Rollema, H. S., Casein Association and Micelle Formation, in Fox, P. F. (Ed.), Advanced Dairy Chemistry, Elsevier Applied Science, Barking, Essex, 1992, pp 111-140. 